\title{
Application of DC-AC Hybrid Grid and Solar Photovoltaic Generation with Battery Storage Using Smart Grid
}

\author{
Shoaib Rauf and Nasrullah Khan \\ Department of Electrical Engineering, Comsats Institute of Information Technology, Islamabad/UOGHH, Islamabad, Pakistan \\ Correspondence should be addressed to Shoaib Rauf; engr.shoaib@uog.edu.pk
}

Received 6 May 2017; Revised 16 July 2017; Accepted 6 August 2017; Published 5 September 2017

Academic Editor: Mahmoud M. El-Nahass

Copyright (c) 2017 Shoaib Rauf and Nasrullah Khan. This is an open access article distributed under the Creative Commons Attribution License, which permits unrestricted use, distribution, and reproduction in any medium, provided the original work is properly cited.

\begin{abstract}
Smart grid for the past few years has been the prime focus of research in power systems. The aim is to eliminate load shedding and problematic blackout conditions, further offering cheap and continuous supply of electricity for both large and small consumers. Another benefit is to integrate renewable energy resources with existing dump grid in more efficient and cost-effective manner. In past few years, growing demand for sustainable energy increases the consumption of solar PV. Since generation from solar PV is in DC and most of the appliances at home could be operated on DC, AC-DC hybrid distribution system with energy management system is proposed in this paper. EMS helps to shift or control the auxiliary load and compel the users to operate specific load at certain time slots. These techniques further help to manage the excessive load during peak and off peak hours. It demonstrates the practical implementation of DC-AC network with integration of solar PV and battery storage with existing infrastructure. The results show a remarkable improvement using hybrid AC-DC framework in terms of reliability and efficiency. All this functioning together enhances the overall efficiency; hence, a secure, economical, reliable, and intelligent system leads to a smart grid.
\end{abstract}

\section{Introduction}

Renewable energy resources such as solar photovoltaic (PV) became more popular over the last decade due to increasing environmental awareness and tax exemption policies on the solar PV systems by the government of Pakistan. Integration of solar PV using various smart load management techniques will boost the efficiency of the overall system by reducing the massive cost of electricity bills. The continuing fear about limited resources of fossil fuels and abrupt change in environmental conditions have pinched the consideration of power generation using renewable energies. World leading countries are also giving incentives to encourage the integration of these renewable energy sources (RES) with our existing systems [1]. Therefore, increasing demand for these RES further enhances its credibility and unlocks different ways for individuals to utilize this cheap energy in this expensive world. But still, there is a need to find efficient and expert ways to enjoy these RES exclusively.
Recent developments in RES such as solar PV provide magnificent opportunities for concrete implementation of smart grid at individual level with further advancement of integration of battery storage and self-switching or controlling of smart appliances automatically. Hence, foremost achievement is the utilization and absorption of smart grid technologies using smart load management schemes in residential region, which in result gears to lessen energy price plus demand management more smartly.

There is a threat of running down of natural resources like coal, gas, and fuel; time is not so far off when a severe decline in the natural resources will be faced [1]. Therefore, efficient use of these resources is a key route to deal with the ever increasing crisis in energy sector. Environmental awareness from local and foreign platforms has made the clean power demand progressively significant [2]. Integration of renewable energy resources in existing system is going wild; therefore, proper results are not achieved yet due to the lack of professionals. There are many individuals working on 
Solar energy potential map of Pakistan

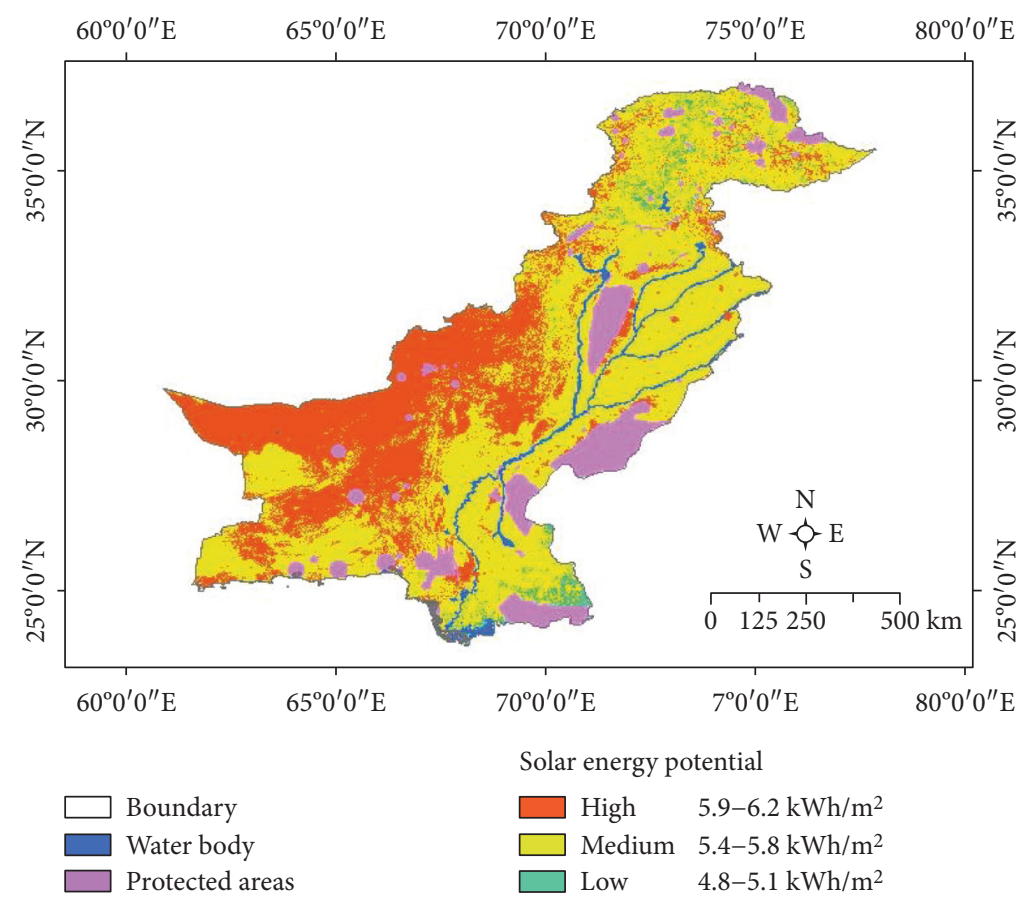

Figure 1: Solar energy potential map of Pakistan.

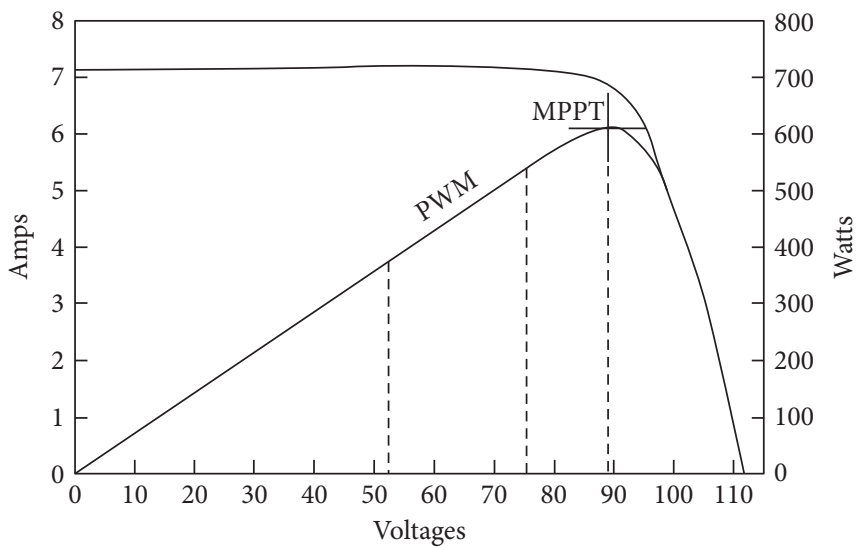

FIGURE 2: Maximum power point tracking curve.

RES in Pakistan with zero acquaintance of the current state of the art; however, proper designing and installation can lead to a more reliable system using smart grid. This could be done at local level with continuous supply of electricity for both large and small scale consumers. Both solar and wind generation is possible but solar PV is more preferable in Pakistan as compared to wind-based energy generation. Solar energy potential map of Pakistan in Figure 1 shows that 35\% of total area lies in the range of $5.9-6.2 \mathrm{kWh} / \mathrm{m}^{2}$ whereas $45 \%$ lies in the range of $5.4-5.8 \mathrm{kWh} / \mathrm{m}^{2}$ and $20 \%$ lies in the range of $4.8-5.1 \mathrm{kWh} / \mathrm{m}^{2}$ [3].

Wind energy is not economical for local generation neither it is available throughout the year in most of the areas of Pakistan. Also, wind mills produce noise that is not bearable and acceptable for residential areas hence is needed to be installed in outskirts which also increase power transmission problems. Therefore, the most economical and practical solution for local power generation is solar PV. Integration of solar PV systems in the present dump grid is the biggest challenge for implementation, planning, and operation of the upcoming smart grid [3]. PV devices along with parallel battery storage need an intelligent system which ensures only solar-based charging during day hours and minimizes the discharging of batteries resulting in a decrease in cost by utility. Utility is only preferred when enough solar energy is not available during day hours to save the battery storage for 
TABLE 1: Different load categories.

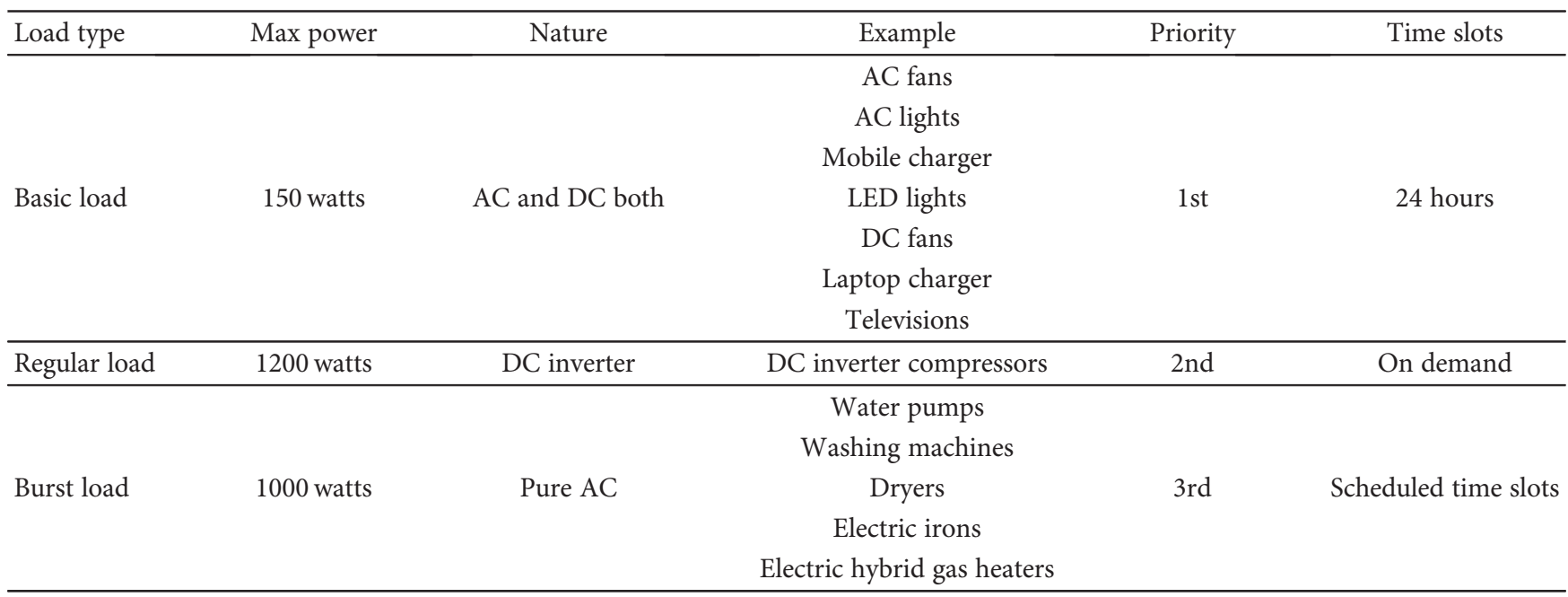

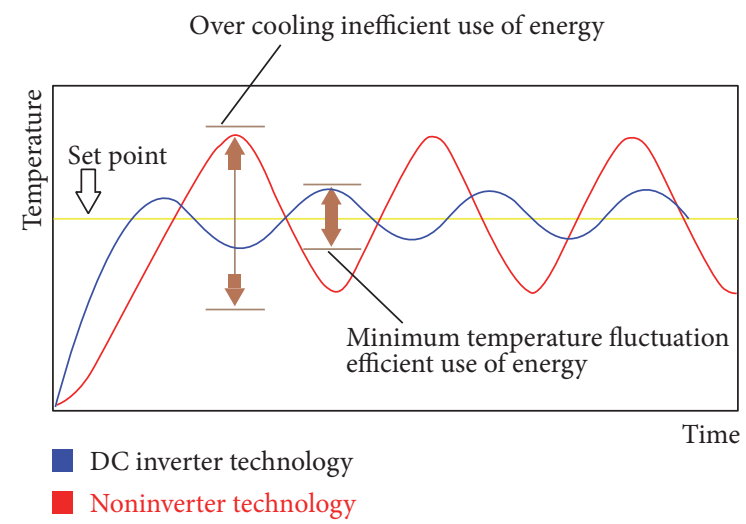

Figure 3: Comparison of DC inverter versus noninverter technology.

night. During night hours, battery storage is used only when utility is not available to avoid complete blackout situation.

Some researches indicate various issues for proper integration of solar PV with existing grid and battery storage system [4]. They also explain multiple ways of setup for battery storage system in smart grid. Authors in [5] present a small model of DC-DC buck-boost converter which offers desired DC voltage level for specific DC appliances. However, authors in [6, 7] focused on the perfection of energy productivity in solar PV systems. They introduced many ways to increase the efficiency of solar PV systems. They analyzed and surveyed the proposed approaches for increasing the efficiency of the said system. It was found that maximum power point tracking (MPPT) along with battery charging and discharging techniques plays a vital role for maximum efficiency in solar PV systems. Authors in [8-10] also described the same approach for the maximum power tracking as shown in Figure 2. They presented an analysis of different load models in $[11,12]$. They considered different static load models in

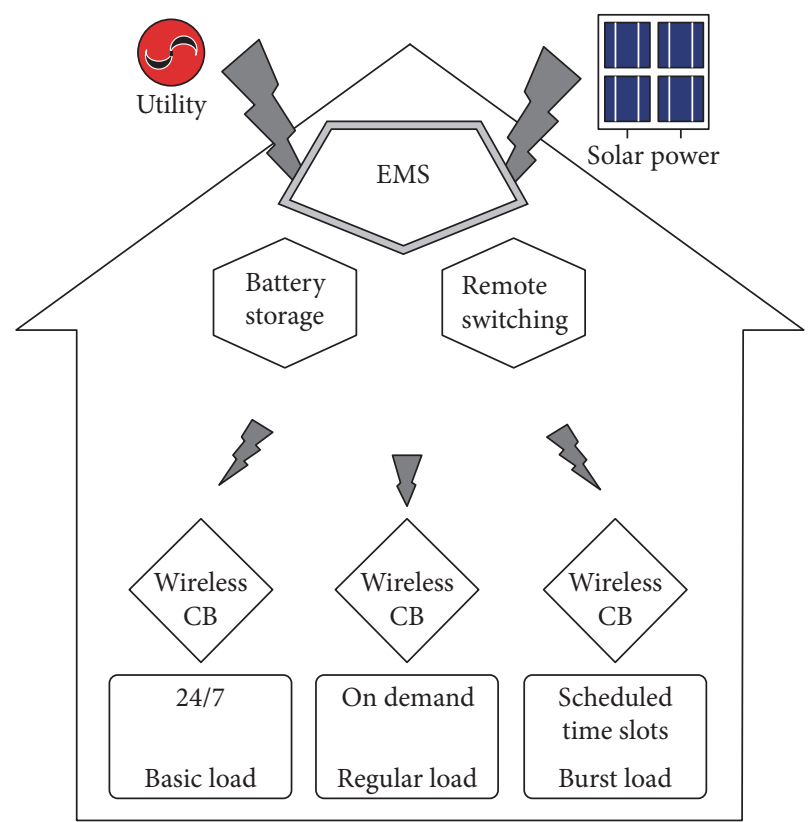

FIgURE 4: Architecture of the system.

[11] for energy efficiency, and these models are further implemented in [13] for more realistic problem at major delivery load point. Load demand and power generation by solar PV keep on changing with respect to time and weather conditions.

In the field of smart grid in last few years, numerous discoveries have been made. Their goal is to make the existing system more reliable, cheaper, economical, and smarter to cater the current power supply demand using smart grid in addition to utilizing maximum solar PVdistributed generation. Proper use of rooftop solar array systems has turned out to be truly useful for local homebased practices. There is about $22 \%$ loss of power due to various conversions from DC-AC and then AC-DC. Most 
TABLE 2: Average power consumption without efficient load.

\begin{tabular}{|c|c|c|c|c|c|c|c|c|}
\hline \multirow{2}{*}{ Load type } & \multirow{2}{*}{ Items } & \multirow{2}{*}{ Watts } & \multicolumn{3}{|c|}{ Summer months } & \multicolumn{3}{|c|}{ Winter months } \\
\hline & & & Hrs/day & Days/wk & WH/day & Hrs/day & Days/wk & WH/day \\
\hline \multirow{5}{*}{ Basic load } & Lights & 200 & 6 & 7 & 1200 & 8 & 7 & 1600 \\
\hline & Fans & 400 & 10 & 7 & 4000 & 0 & 0 & 0 \\
\hline & Router & 15 & 24 & 7 & 360 & 24 & 7 & 360 \\
\hline & TV & 75 & 4 & 7 & 300 & 5 & 7 & 375 \\
\hline & PCs & 80 & 4 & 5 & 228 & 5 & 5 & 285 \\
\hline \multirow{2}{*}{ Regular load } & Fridge & 480 & 7 & 7 & 3360 & 3.5 & 7 & 1680 \\
\hline & ACs & 1800 & 5 & 4 & 5142 & 0 & 0 & 0 \\
\hline \multirow{4}{*}{ Burst load } & Pump & 1600 & 1.5 & 7 & 2400 & 1 & 7 & 1600 \\
\hline & Iron & 1000 & 0.25 & 5 & 178 & 0.25 & 5 & 178 \\
\hline & Washer & 320 & 1.5 & 2 & 137 & 1.5 & 1 & 68 \\
\hline & Cleaner & 2000 & 0.5 & 2 & 285 & 0.5 & 1 & 142 \\
\hline Total & & & \multicolumn{3}{|c|}{$17592 \mathrm{Wh} /$ day } & \multicolumn{3}{|c|}{$6290 \mathrm{Wh} /$ day } \\
\hline
\end{tabular}

TABle 3: Average power consumption with efficient load.

\begin{tabular}{|c|c|c|c|c|c|c|c|c|}
\hline \multirow{2}{*}{ Load type } & \multirow{2}{*}{ Items } & \multirow{2}{*}{ Watts } & \multicolumn{3}{|c|}{ Summer months } & \multicolumn{3}{|c|}{ Winter months } \\
\hline & & & Hrs/day & Days/wk & WH/day & Hrs/day & Days/wk & $\mathrm{WH} /$ day \\
\hline \multirow{5}{*}{ Basic load } & LED lights & 100 & 6 & 7 & 1200 & 8 & 7 & 800 \\
\hline & Fans & 400 & 10 & 7 & 4000 & 0 & 0 & 0 \\
\hline & Router & 15 & 24 & 7 & 360 & 24 & 7 & 360 \\
\hline & TV & 75 & 4 & 7 & 300 & 5 & 7 & 375 \\
\hline & PCs & 80 & 4 & 5 & 228 & 5 & 5 & 285 \\
\hline \multirow{2}{*}{ Regular load } & Fridge (DC inverter) & 160 & 7 & 7 & 1120 & 3.5 & 7 & 560 \\
\hline & ACs (DC inverter) & 800 & 5 & 4 & 2285 & 0 & 0 & 0 \\
\hline \multirow{4}{*}{ Burst load } & Pump & 1600 & 1.5 & 7 & 2400 & 1 & 7 & 1600 \\
\hline & Iron & 1000 & 0.25 & 5 & 178 & 0.25 & 5 & 178 \\
\hline & Washer & 320 & 1.5 & 2 & 137 & 1.5 & 1 & 68 \\
\hline & Cleaner & 2000 & 0.5 & 2 & 285 & 0.5 & 1 & 142 \\
\hline Total & & & & $2493 \mathrm{Wh} / \mathrm{c}$ & & & $368 \mathrm{Wh} / \mathrm{d}$ & \\
\hline
\end{tabular}

of the appliances accept DC power; therefore, they are directly coupled with solar PV and battery storage. For other devices which do not accept DC, conversion problem still prevails. If power is converted from low-level DC voltage to higher-level AC voltage, then it is needed to step-up a low-level voltage from a solar PV to conventional voltage level $(220 \mathrm{~V})$ then further conversion to AC. These solar PV arrays are fed to local grid using different inverters with conversion losses because solar PV produces DC supply and existing utility accepts AC only. Series combination of solar panels thus adds up the voltage to the desired level instead of using step-up transformers to avoid the transformer as well as conversion losses.

1.1. Objectives of Work. The following are a few objectives for this work:

(i) Continuous supply of power during hours of unplanned load shedding at domestic level (ii) Utilizing maximum solar energy to reduce expensive utility tariff

(iii) Reducing the dependency of consumer on utility by interacting with both utility and the end user

(iv) Compelling the system to bring the interest of both consumer and utility at a single platform in order to reduce the demand charges

(v) Rescheduling maximum power-consuming tasks during hours of maximum PV generation

(vi) Managing regular load more efficiently using feedback from weather forecast

(vii) DC microgrid implementation to reduce power conversion losses for basic load

(viii) Different series and parallel combination of solar PV array to reduce line losses for high-rise buildings 


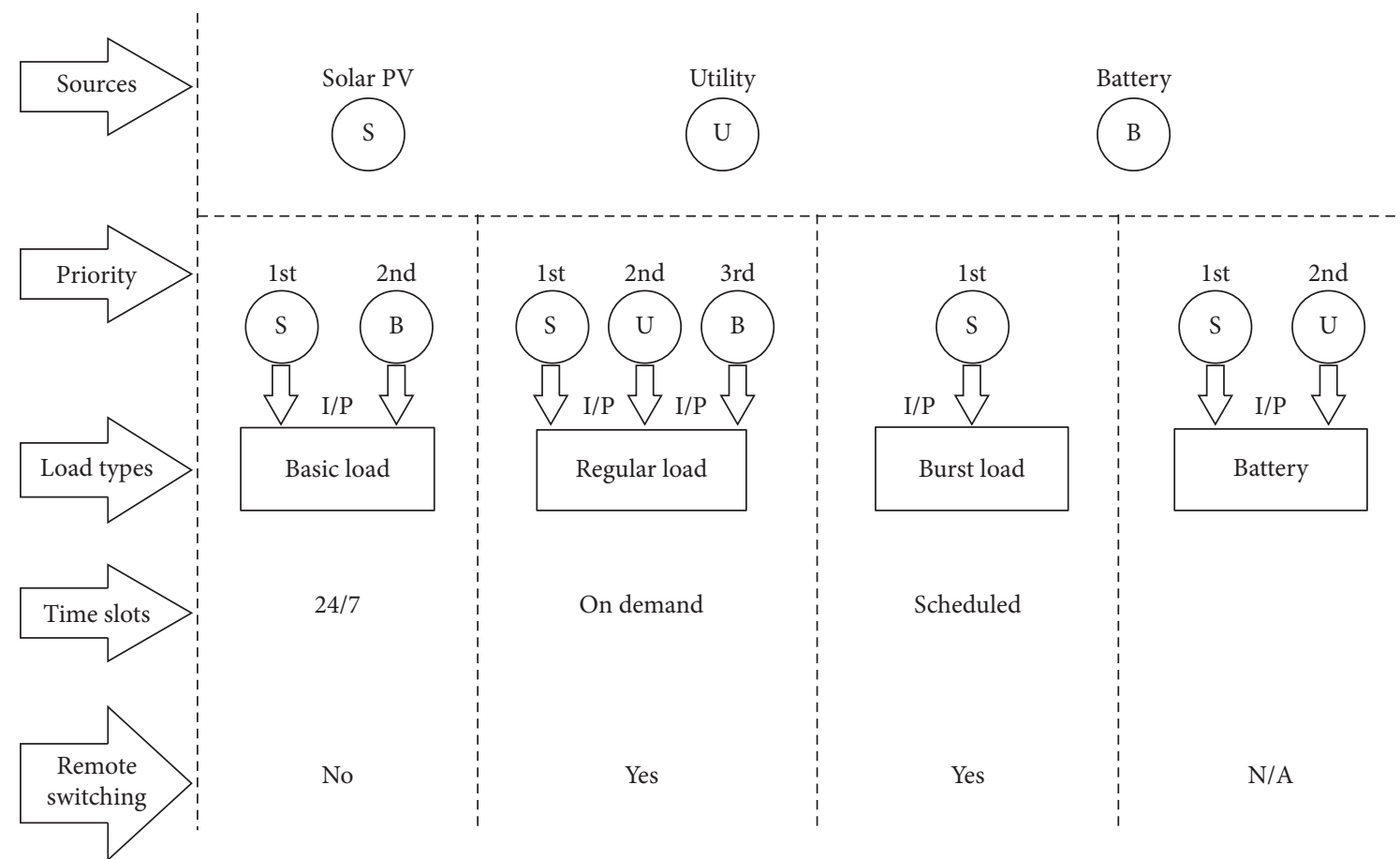

Figure 5: Control layout of the system.

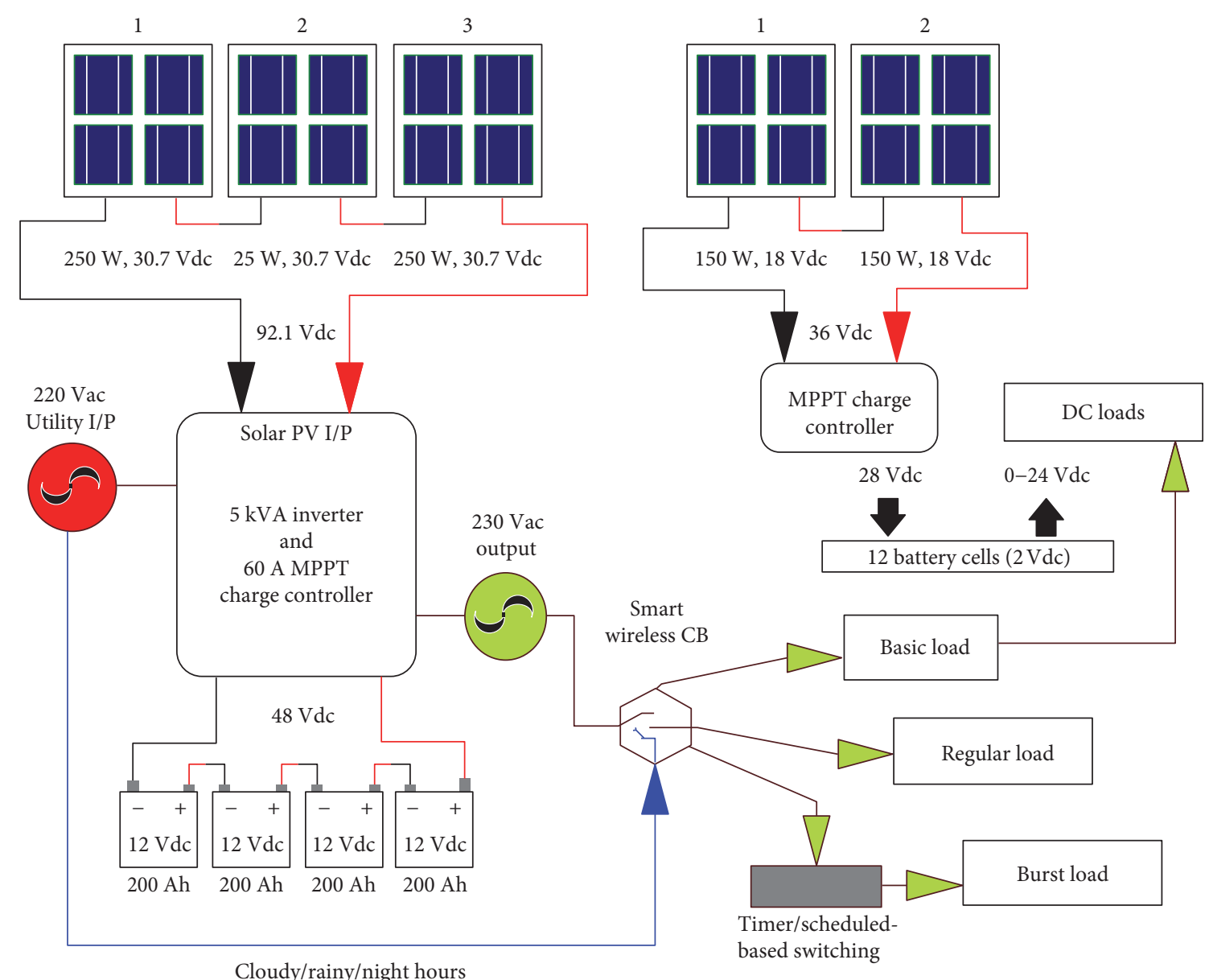

Figure 6: A smart system model. 


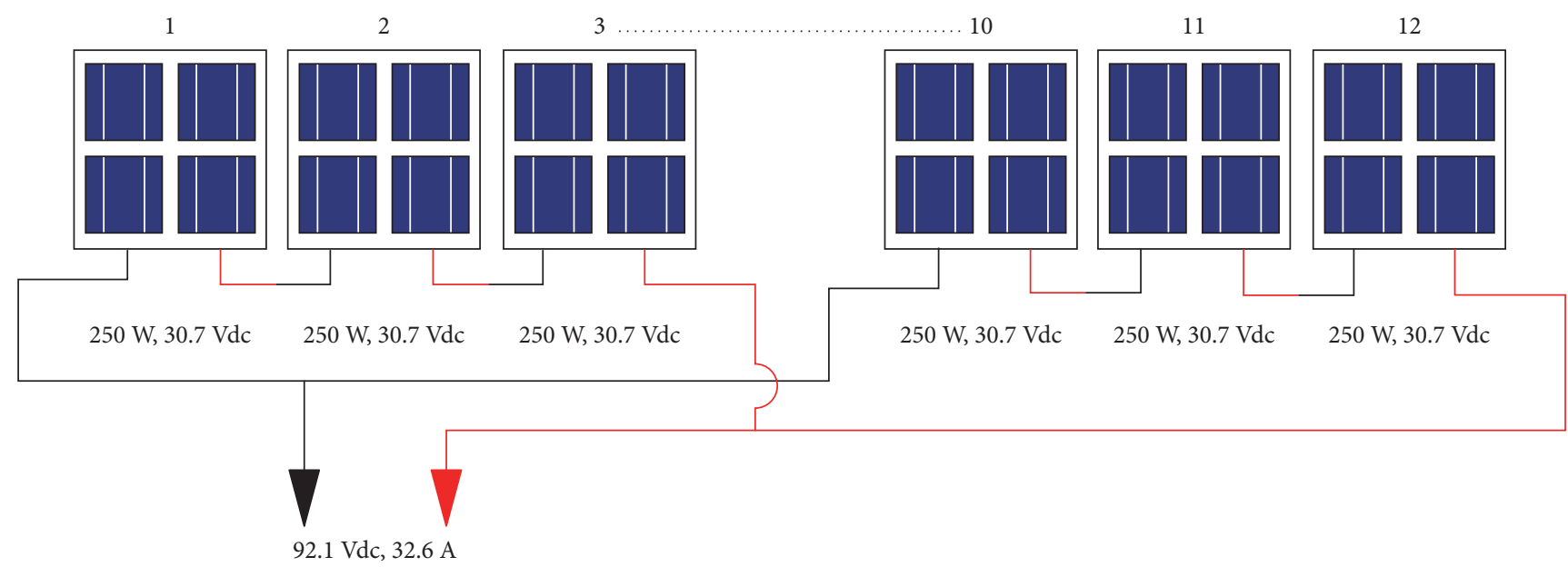

FIGURE 7: Series and parallel combination of solar PV panels.

(ix) Smartly managing battery storage by shifting load back to utility in order to minimize battery discharge

(x) Remotely control specific machine using wireless circuit breaker and rescheduling a healthy time slot because up to $40 \%$ of load could be decreased if considering washing and drying only.

1.2. Load Classification. The system design includes the ability to interact with both utility and end users, which can be modified according to the consumer desire. Depending upon the availability of supply, from both utility and solar power generation, demand side load management can be done. Load forecasting could be done depending upon the availability of power from solar PV. Different incentives in favor of end users and supply side help to bring both allies on a common platform. This platform encourages and involves the concern from both parties so that it is more practical and regulates the system more smoothly. We define load in three different categories as shown in Table 1.

Basic load is defined as the load with 1 st priority, and maximum power rating for each appliance is 150 watts. This load is needed 24 hours a day without any interruption. 35$42 \%$ of total load is basic load due to varying weather conditions [14]. It is maximum during summers and minimum during winter season. Nature of this load is both AC and DC such as conventional AC lights and fans. In addition to this, it also involves DC load such as mobile, laptop chargers, televisions, PCs, and LED lights. It can prevent conversion restrains by utilizing solar DC power directly for DC devices.

Regular load involves air-conditioning and refrigeration loads with DC inverter technology. It involves DC compressors instead of AC. DC motors coupled with these compressors make system more efficient. It saves up to $50 \%$ of power as compared to existing compressors for both air-conditioning and refrigeration systems. Second priority is defined for these systems. This load also varies with seasonal changes. During summers, it is at its peak comprising almost $48 \%$ of total load, and during winter,
TABLE 4: Specification of $250 \mathrm{~W}$ solar PV.

\begin{tabular}{lc}
\hline Rating power & $250 \mathrm{~W}$ \\
Rating power voltage & $30.7 \mathrm{~V}$ \\
Rating power current & $8.15 \mathrm{~A}$ \\
Open-circuit voltage & $38.10 \mathrm{~V}$ \\
Short-circuit current & $8.80 \mathrm{~A}$ \\
\hline
\end{tabular}

TABLE 5: Specification of EMS.

\begin{tabular}{lc}
\hline Voltage & $230 \mathrm{Vac}$ \\
Frequency & $50 \mathrm{~Hz}$ \\
Voltages & $230 \mathrm{Vac}$ \\
Efficiency & $93 \%$ \\
Transfer time & $10 \mathrm{~ms}$ \\
Waveform & Pure sine wave \\
Battery voltages & $48 \mathrm{Vdc}$ \\
Floating charge voltage & $54 \mathrm{Vdc}$ \\
Overcharge protection & $60 \mathrm{Vdc}$ \\
Maximum PV array & $3000 \mathrm{~W}$ \\
MPPT voltage range & $60 \mathrm{Vdc}-115 \mathrm{Vdc}$ \\
Maximum PV array open-circuit voltage & $145 \mathrm{Vdc}$ \\
Maximum solar charger current & $60 \mathrm{~A}$ \\
\hline
\end{tabular}

$27 \%$ of the total load. Figure 3 shows comparison of both the technologies [15].

Burst load is used during specific time slots; they may vary with respect to different activities. $31-35 \%$ of the overall load is burst load. As it may vary with daily routines, it could be rescheduled on specific time slots, at the time of maximum solar power generation. Depending upon the weather conditions, this load can be varied. The common examples of these activities are ironing, washing, drying, and heating.

Figure 4 shows the basic architecture of the combined system. In order to apply the EMS smartly to residential 


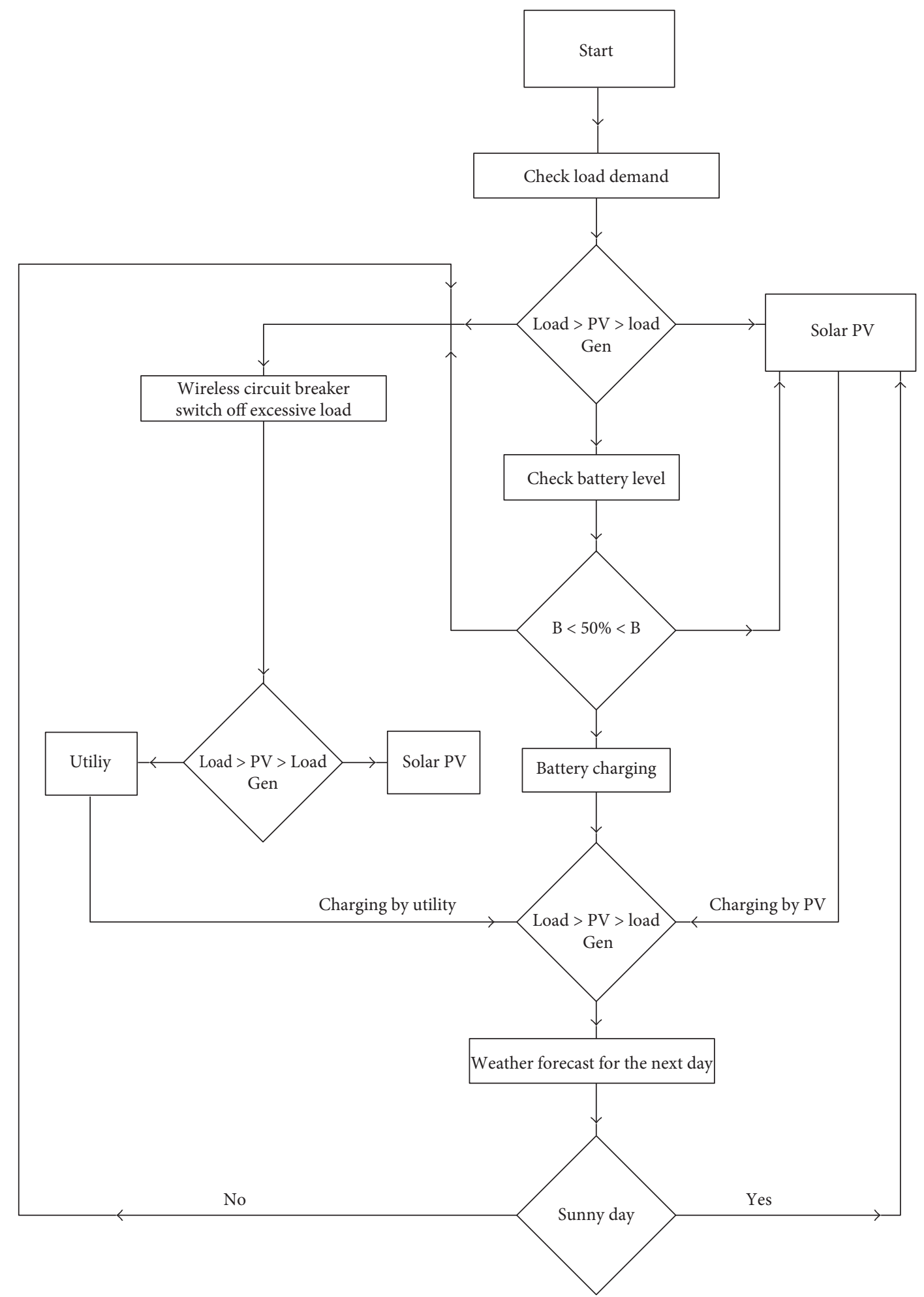

FIgURE 8: Flow diagram for EMS during summer.

houses, load such as regular load and burst load appliances must be put into a special range. This special range of loads is needed to add with a wireless transmitter and data process. These communication devices give birth to a more intelligent and efficient system. They could be operated automatically during an appropriate time interval on the availability of energy resources. However, it would be better if user could centralize the load management of all smart appliance using EMS. In this paper, we introduce the most generalized architecture of EMS in a residential load with an additional feature of using DC appliances. This feature further enhances the overall functionality, stability, and efficiency by reducing 
TABLE 6: Backup time for different load.

\begin{tabular}{lc}
\hline Load (VA) & Backup time @ 48 Vdc 200 Ah batteries (min) \\
\hline 500 & 1152 \\
1000 & 576 \\
1500 & 384 \\
2000 & 288 \\
2500 & 230 \\
3000 & 192 \\
3500 & 164 \\
4000 & 144 \\
4500 & 128 \\
5000 & 115 \\
\hline
\end{tabular}

the DC-AC-DC conversion losses. It also presents an approach to schedule the electricity consumption to reduce electricity cost.

For this approach, the final results of experimental work prove its feasibility and effectiveness for local user. Table 2 shows the average power consumption for existing load [14]. Replacing the existing lighting load by LED lights for basic load reduces the overall load by $50 \%$ as shown in Table 3. Since this reduction in load enhances the overall efficiency of the system, introducing DC inverter technology for regular load further decreases $60 \%$ of the load. It also reduces load consumption and achieves reduction in peak load demand and operational cost for the users.

\section{Energy Management System}

Besides providing the connection between different loads, this system has the ability to collect information and execute control commands for the households. It provides continuous observations and acquires information about both load and supply profile, convincing the end user to take preventive measures by switching the auxiliary load to save power for extreme conditions. These extreme conditions are defined by users using their routine power consumption to avoid complete blackout conditions. Users can control the operation of the whole system from a set of predefined states according to their requirements as shown in Figure 5. These operations can further be upgraded using different factors like weather and load forecasting. This guarantees the enhanced function of the local grid and permits the consumers to regulate their power accordingly.

A smart storage is proposed for the off-grid DC loads. A series connection of $2 \mathrm{Vdc}$ battery cells is used. These battery cells have the capability to store maximum charge in the form of ampere hours with potential difference of $2 \mathrm{Vdc}$. A total of 12 cells are connected in series, so it could produce $24 \mathrm{Vdc}$. This proposal is further explained later.

According to the proposed design, the rooftop is covered with solar PV which connects directly to the energy management system. Series combination of solar PV panels reduces the voltage drop in solar output voltage and also the power transmission losses. Both AC and DC supply lines are

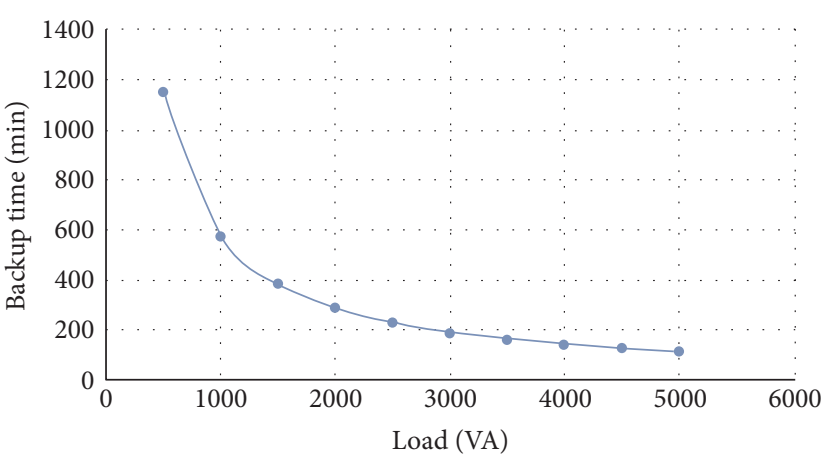

Figure 9: Backup time versus power consumed by load.

TABLe 7: Voltage level for DC appliances.

\begin{tabular}{lc}
\hline DC voltage levels & DC appliances \\
\hline $5 \mathrm{Vdc}$ & Mobile, iPad \\
$12 \mathrm{Vdc}$ & Led light, DC fan \\
$18 \mathrm{Vdc}$ & Laptop charger \\
$24 \mathrm{Vdc}$ & Television, DC motor \\
\hline
\end{tabular}

directly connected with AC and DC load lines within the built-in wiring of the house. A $92.1 \mathrm{Vdc}$ from solar is fed to the EMS. This system accepts power from both solar PV and utility and supplies power to three types of loads as mentioned before. Smart wireless circuit breakers are installed at specific load, such as burst and regular loads. Depending upon the generation, EMS will distribute power among all connected loads at different time slots. It will acquire data from current and potential transformers, installed at supply side of PV generation and with the load. Graphical user interface is installed with EMS, which allows the monitoring of different variables such as solar PV generation, connected load, and battery voltage. Using power generation profile from solar PV, EMS will decide the priorities for every single load type and electrify the specific load. During the hours of maximum generation, EMS will send notifications via SMS to the users to regulate their specific tasks. These notifications are alarm based and via SMS through GSM module connected with EMS. Smart wireless circuit breakers installed at specific loads further enable both consumers and utility to control the excessive load remotely. Combined system architecture is shown in Figure 6.

This system helps to manage both AC and DC load simultaneously, on the basis of exact calculation of load demand. Figure 6 shows $3 \mathrm{~kW}$ of solar input power for regular and burst load and $0.6 \mathrm{~kW}$ for basic load. Figure 7 shows twelve monocrystalline solar panels, each of 250 watts, connected in series and parallel combination to sum up voltage level of $92.1 \mathrm{Vdc}$.

Series connections add up voltages which decrease the transmission losses, and further, parallel connections add up current. Current and voltage specification for each solar PV panels is shown in Table 4. 


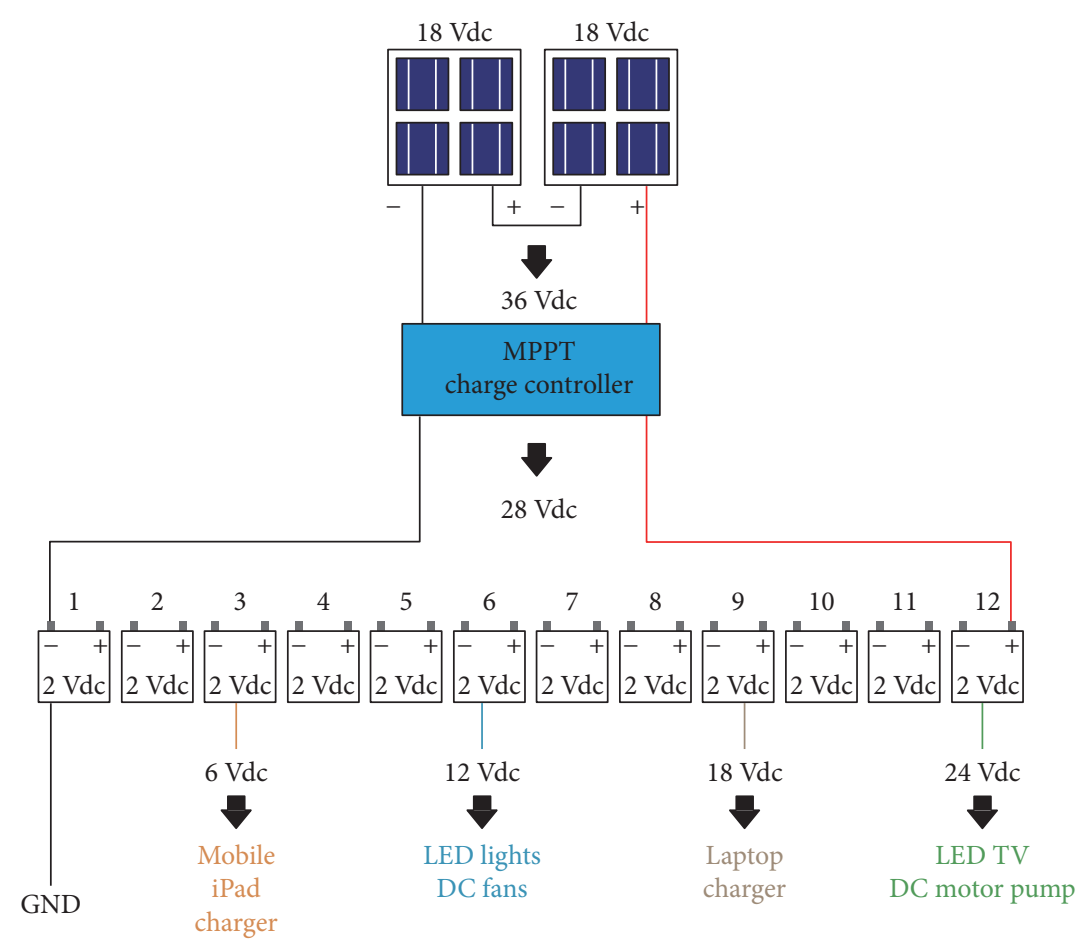

FIGURE 10: Schematic diagram for DC Loads.

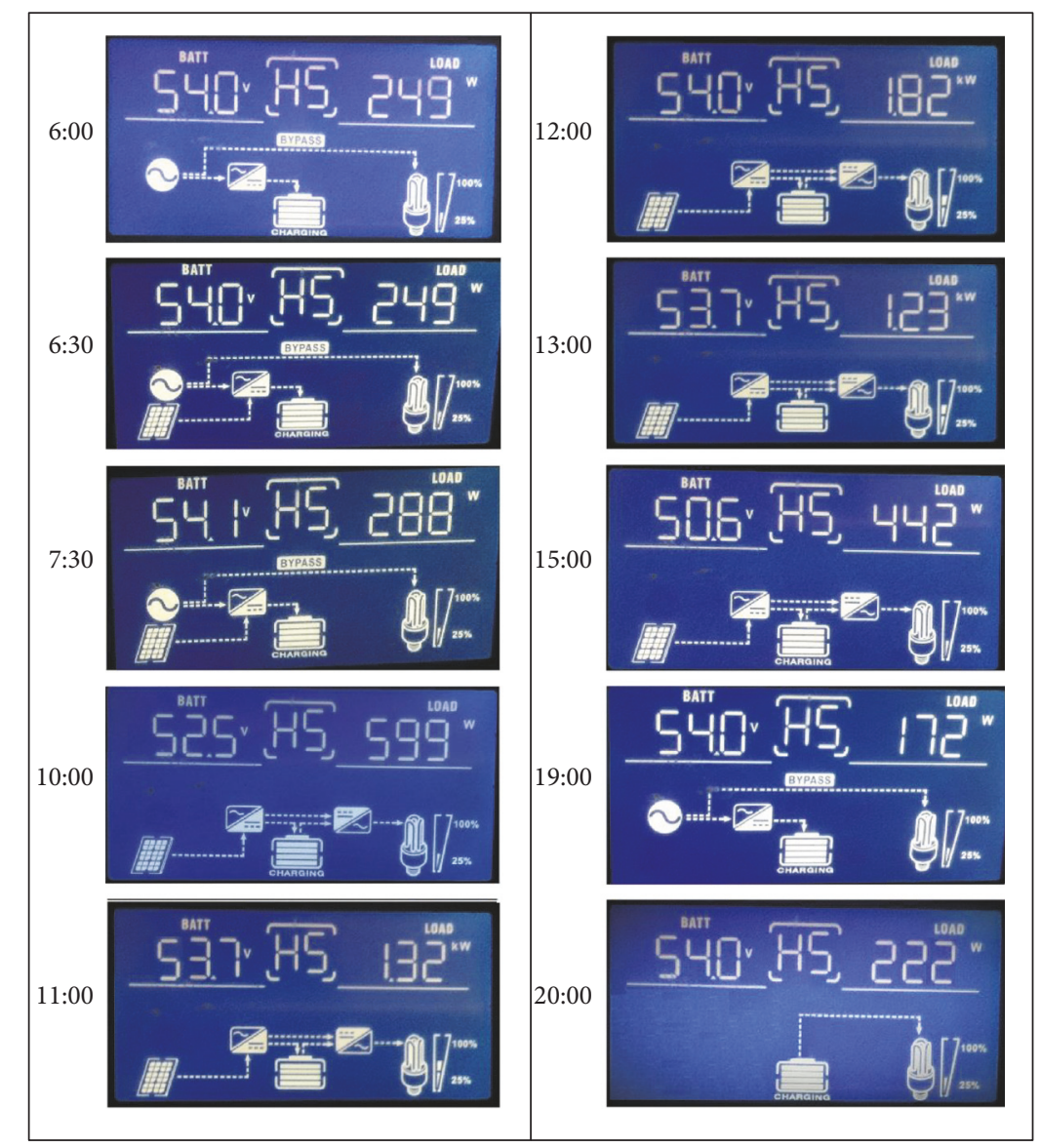

FIGURE 11: Status of battery and connected load. 


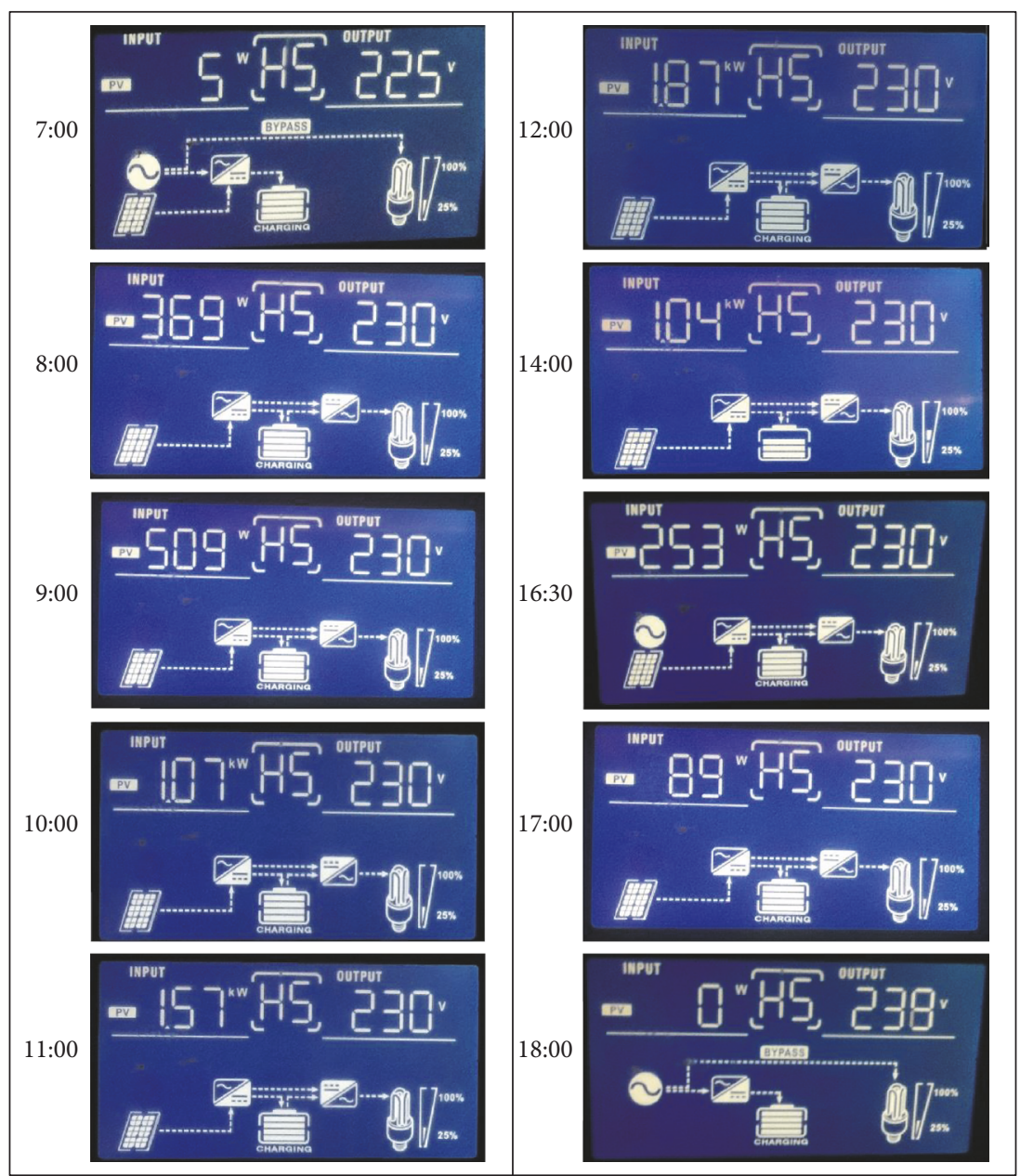

FIGURE 12: Status of PV generation and output of inverter.

A $5 \mathrm{kVA}$ hybrid inverter is designed for AC loads; it produces pure sine wave with built-in MPPT charge controller. Table 5 shows specification of EMS.

\section{Flow Chart for EMS}

Different priorities for output of inverter are set to configure load. "Solar first" priority will allow utilization of solar energy at first priority from solar PV array. If sunshine is not at peak and is unable to produce maximum power for all connected load, then smart wireless circuit breaker will turn off the less priority load, which could be defined by the user. Total load at home could be varied with respect to different activities at home, such as washing, drying, and ironing. This smart system will check with weather forecast regularly and suggest different future time slots for these activities; it will also check for battery storage. Even though, utility charging is available, but in order to minimize utility cost, solar charging will be preferred.

Battery storage would be the last priority at night hours only when utility and solar are both not available. During worst condition, only basic load could be switched on, and the auxiliary load will be shut down until next optimum condition. The optimum conditions occur only when any of the sources, either solar or utility, is available. If utility is available and battery storage is facing critical situation, then load demand for regular load and battery charging could be accomplished from this source. This scheme of working helps to minimum discharging of batteries, thereby increasing their life as batteries have limited number of cycles for both charging and discharging.

The case study in this paper is based on the power generation and its usage in summer only because, as observed in Table 3, there is $65 \%$ more power consumption in summers as compared to that in winters. This increase in power demand is due to excessive use of cooling appliances in summers. The flow diagram of EMS as shown in Figure 8 is further implemented in Section 5, using graphical and numerical values. The same scheme can easily be implemented for winters as power consumption is very low.

During day hours, solar PV provides power to both the load and battery charging simultaneously. If the solar is not able to supply power, then the load will be shifted to utility, and the batteries will still be charged by solar. Load forecasting could be done by using the following equation. Table 6 

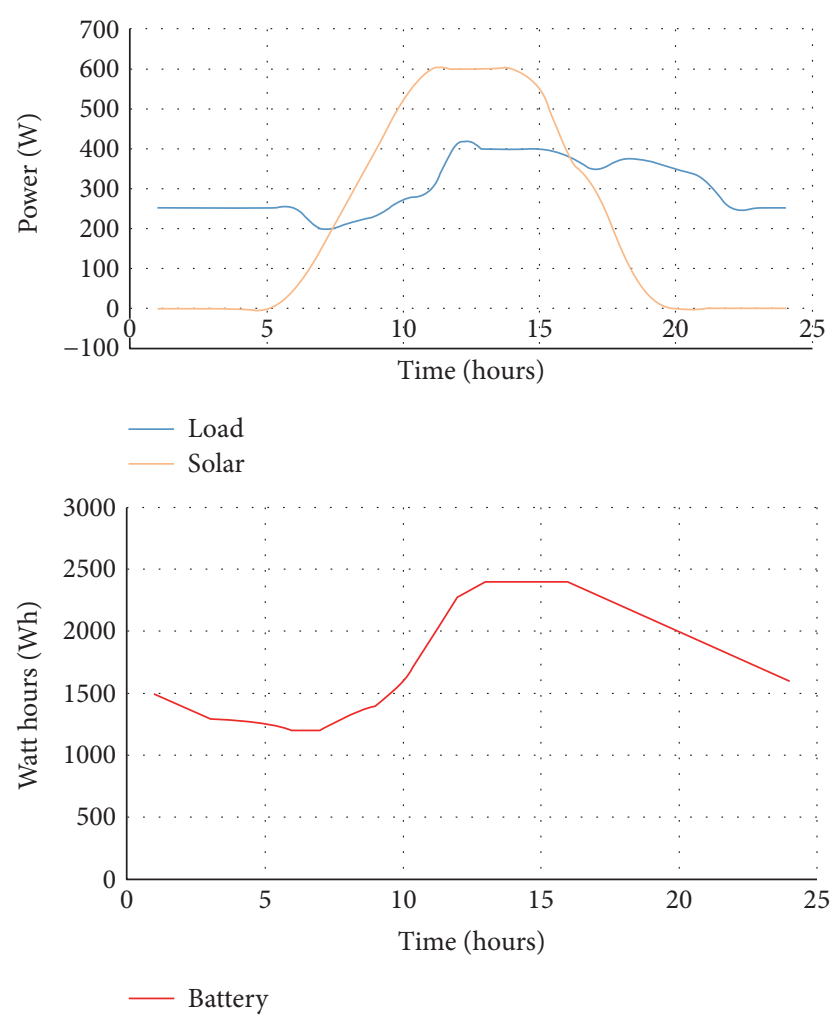

Figure 13: Graphical profile for basic load.

shows values for backup time for different loads, and Figure 9 shows graph for backup time and power consumed by load.

$$
\begin{aligned}
\text { Load amperes } & =\frac{\text { Power }}{\text { Voltage }} \\
\text { Backup time } & =\frac{\text { Battery ampere hours }}{\text { Load amperes }} .
\end{aligned}
$$

\section{DC Microgrid}

DC microgrid does not need the scheduling because the DC load it runs is the basic load which is less than 150 watts. This load category defines the load that can be run on DC power, such as LED lights, televisions, mobile, and laptop chargers. Table 7 shows different input voltage ranges for DC appliances included in basic load.

DC microgrid used for DC loads involves series combination of both solar PV and $2 \mathrm{Vdc}$ battery cells. The use of $2 \mathrm{Vdc}$ battery cells eases the accessibility of the desired volts as per load requirement for varied DC voltage levels as shown in Figure 10. It is further specified using DC-DC converters. It allows both DC load and power supply from solar PV to link directly thus reducing the conversion losses.

The DC system is used to lessen the conversion losses and uplift the efficiency of the entire system. Additionally, it offers a backbone grid within the whole system to empower DC loads and increase its overall reliability. It directly electrifies the DC load with the batteries which are also DC based thus eliminating the need of power
TABLE 8: Battery bank system.

\begin{tabular}{lc}
\hline Specifications & Values \\
\hline $2 \mathrm{Vdc}, 100$ Ah battery cell & 12 cells \\
Volts $\times$ amperes $\times$ number of cells $=$ & $2 \mathrm{Vdc} \times 100 \mathrm{Ah} \times 12$ \\
max battery bank capacity $(\mathrm{Wh})$ & cells $=2400 \mathrm{Wh}$ \\
Charging efficiency $(\%)$ & 90 \\
Minimum and maximum storage & $50 \%-100 \%$ \\
Life cycles for charging and discharging & 2000 \\
Cost per cycle usage & $0.10 \mathrm{Rs} / \mathrm{kWh}$ \\
\hline
\end{tabular}

conversion for AC transmission. DC systems have zero frequency; thus, it is much easier to monitor and control load profile [16]. DC transmission is much efficient than AC power transmission [17]. DC systems are applied in various systems such as in submarine and ship. DC systems are also used in many off-grid homes and stand-alone systems [18]. Nowadays, most of the IT data centers are moving towards DC power source which is almost 20\% more energy efficient than existing AC supplies [19]. A twoway power transfer is also possible as these grids could be connected easily with existing AC grids using inverters which make the overall network more reliable. Increased efficiency is a trade-off for additional cost of this DC system. There are few major hurdles such as large scale employment, regularization, and safety for DC systems which still need to be worked on in order to be accepted 


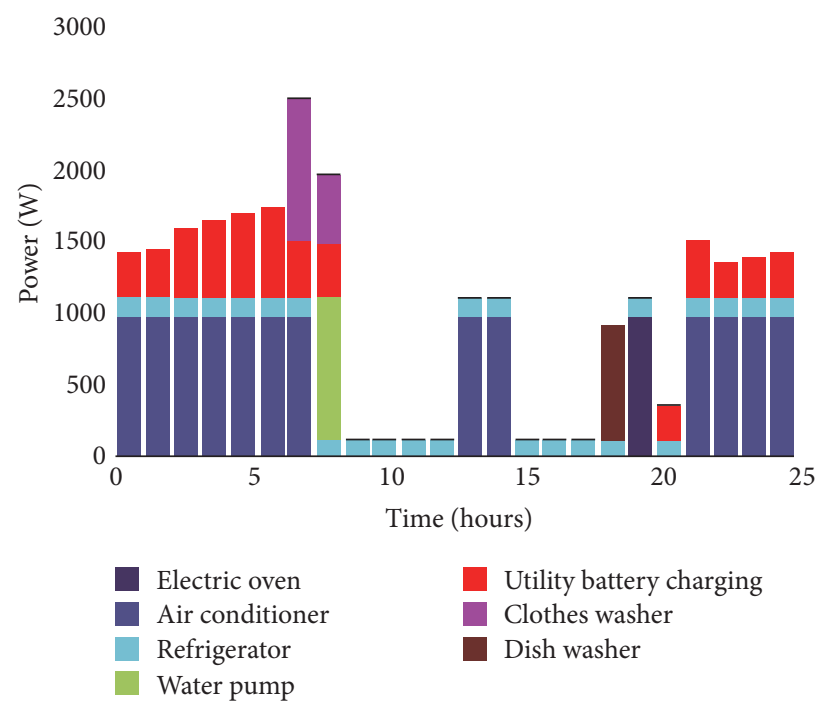

FIGURe 14: Power consumption by different type of AC loads.
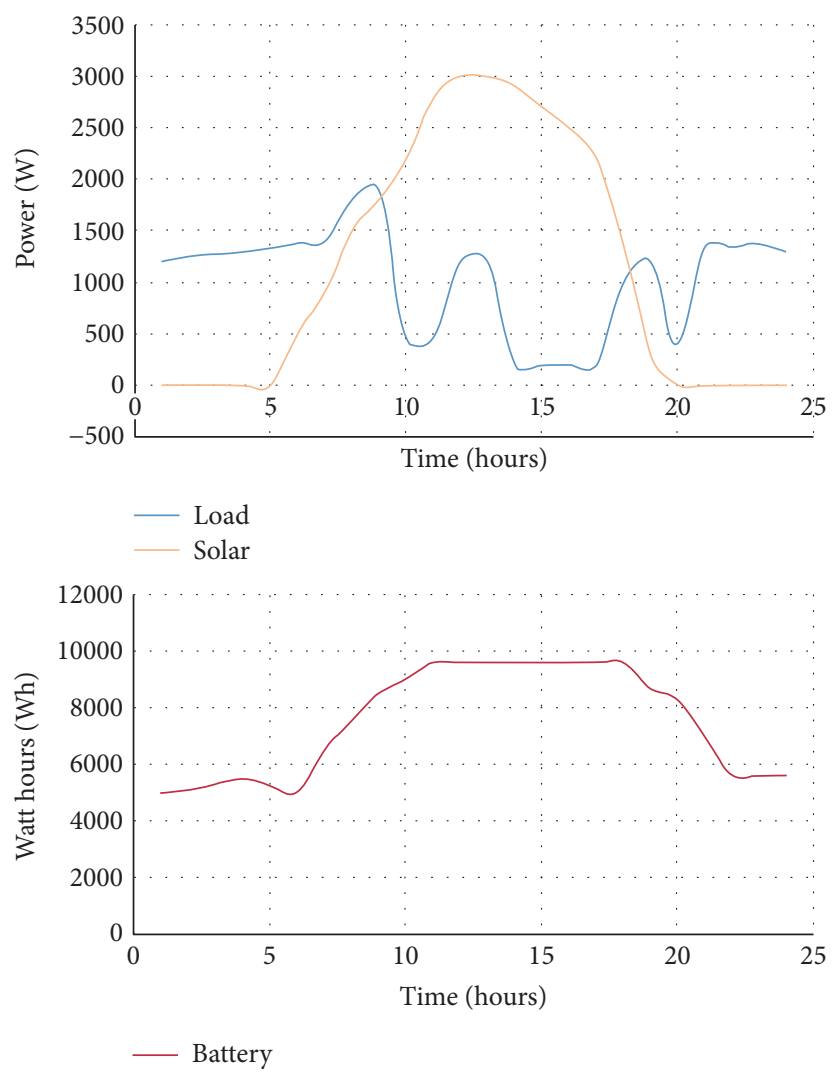

FIGURE 15: Graphical profile for burst and regular load.

in market [20]. Future PV systems connected to low-voltage DC grids are expected to be more effective in performance and support the entire grid [21].

Solar energy captured by PV arrays generates DC power [22]. Operating the DC appliances directly on DC grid enhances the system reliability and minimizes the conversion losses. Thus, solar PV produces DC power and directly electrifies these devices. Load of individual appliance with maximum power rating of 150 watts falls in this category. These devices are run by directly connecting solar PV panels and battery storage using different series and parallel combinations to get the desired voltage level for individual devices. Further DC-DC converters are used to supply exact power supply to each of these appliances. 

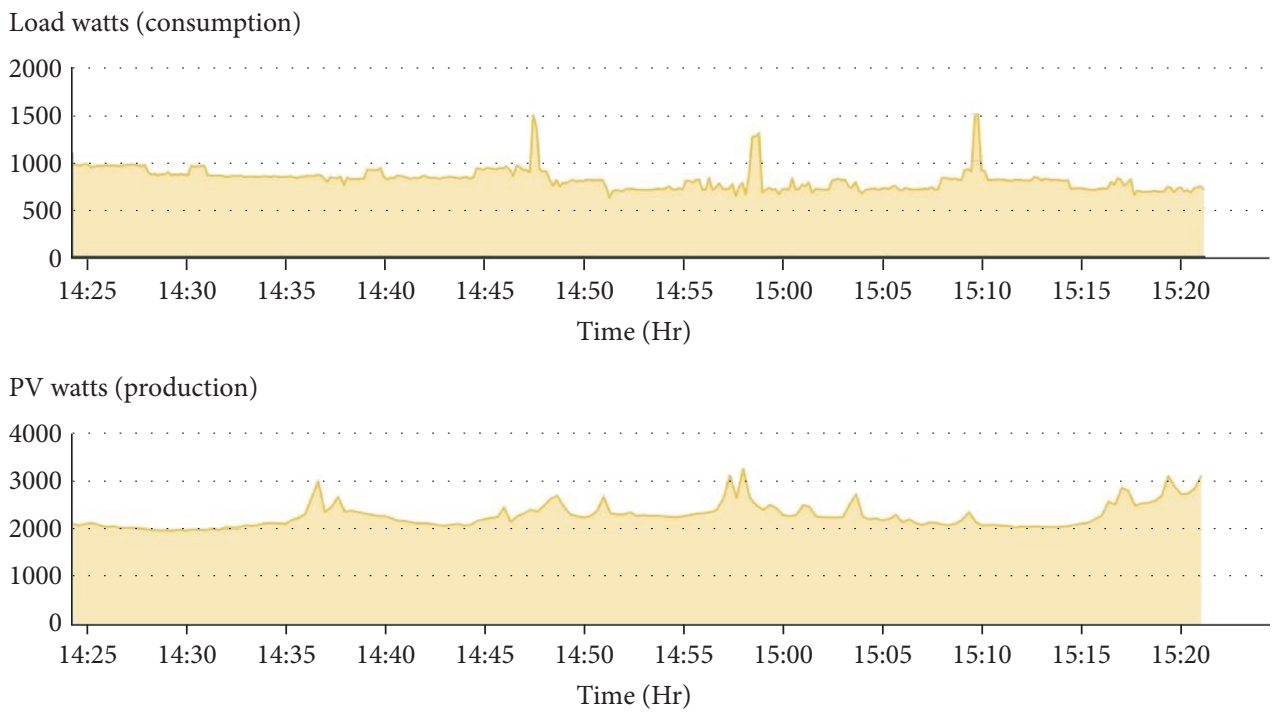

FIGURE 16: Load consumption and PV production.

\section{Implementation and Results}

The above-stated system could be very useful for continuous supply of power with additional feature of cost reduction from utility. To evaluate the system, two houses are observed in rural areas of Punjab, Pakistan during summer season. As the load shedding and power shortage are more observed in summer due to excessive use of refrigerators and air conditioners, one of the houses is equipped with EMS. Both houses have the same load power consumption with the same number of appliances installed. Real-time data is examined for the house with EMS and compared with that for the other without EMS. Figures 11 and 12 show snapshots of graphical user interface for the house with EMS at different time slots during a sunny day in summer. These results show status of connected battery voltage, solar PV generation, and connected load in watts, with additional graphical status of input and output power supplies. At 6:00 in the morning, utility supplies power to both load and battery charging as solar is not available. The battery will remain full and further boost battery storage. Similarly, at 6:30, solar input is not sufficient to fulfil all connected load but will charge the battery storage in order to save charging cost from utility. After 7:30, sunshine is adequately running connected load as well as charging the batteries.

As peak solar PV generation is from 11:00 to 13:00 hours, maximum power-consuming tasks such as washing, ironing, heating, cleaning, and water pumping could be scheduled at this time slot. Acquiring data from local weather forecasting will further help to predict different days for such activities. DC inverter compressors are equipped with DC-based motors for both refrigeration and air-conditioning loads and are scheduled to run at maximum speed to achieve maximum cooling during these hours. This cooling effect lasts long and helps to restore temperature during night hours. Further insulation for refrigerators and air-conditioning rooms enhances the temperature coefficient. After sunset,

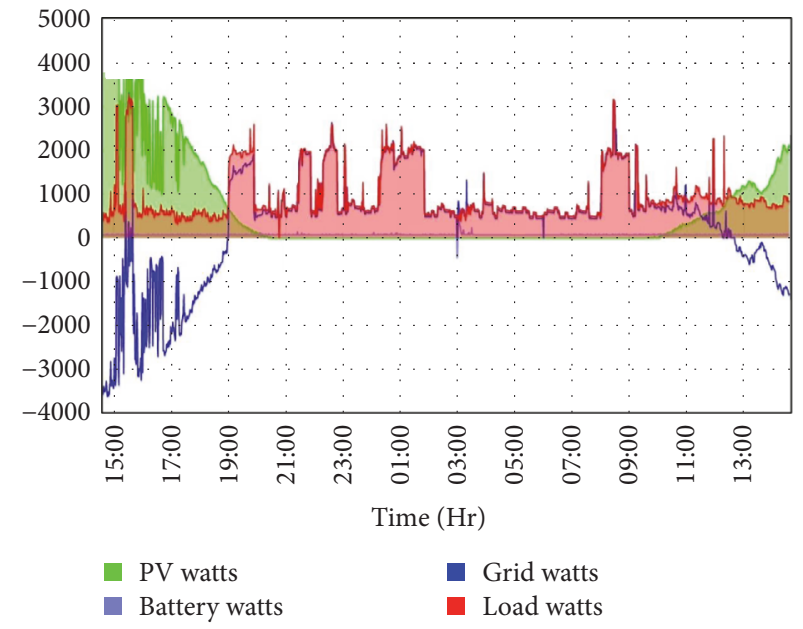

Figure 17: Overview of all the parameters.

utility will have to supply power to all the connected load, and battery storage is used only in the case of load shedding when all supplementary load will also be shutdown. During night hours, DC inverter loads are operated at slow speed; it consumes minimum power and helps to stimulate the cooling effect stored during daytime. Figure 13 shows the graphical representation of the DC load. As mentioned earlier, this type of load is the 1st priority and its time of usage is almost throughout the day.

A 600-watt rooftop PV system is connected with $2400 \mathrm{Wh}$ battery bank with the following specification as shown in Table 8 . The graph shows the data during an average summer day for both solar power generation and load demand with battery storage status with respect to time.

Battery sizing is done in such a way that it could not be discharged fully. The load is managed so that it would not discharge the battery below $50 \%$ thereby saving the battery 
TABLE 9: Cost for EMS.

\begin{tabular}{|c|c|c|c|c|}
\hline Items & Specification & Quantity & Cost/unit (PKR) & Total cost (PKR) \\
\hline Solar PV & $250 \mathrm{~W}$, monocrystalline & 12 & 11000 & 132000 \\
\hline Energy management System & $\begin{array}{l}5 \mathrm{kVA} / 4 \mathrm{~kW} \text { hybrid inverter, MPPT charge controller, } \\
\text { energy management unit, remote circuit breaker }\end{array}$ & 1 & 65000 & 65000 \\
\hline Battery & Lead acid, $12 \mathrm{Vdc}, 200 \mathrm{Ah}$ & 4 & 18000 & 72000 \\
\hline Miscellaneous & Iron bar stands, wire, clamps, labor cost & & 10000 & 10000 \\
\hline Total cost & & & & 279000 \\
\hline
\end{tabular}

TABLE 10: Return on investment.

\begin{tabular}{|c|c|c|c|}
\hline \multirow{4}{*}{ Running cost } & Utility & \multirow{2}{*}{ Without EMS (PKR/month) } & 9499 \\
\hline & Generator fuel & & 6500 \\
\hline & Utility & \multirow{2}{*}{ With EMS (PKR/month) } & 2135 \\
\hline & Generator fuel & & 0 \\
\hline Saving & & (PKR/month) & 13864 \\
\hline ROI & Return on investment & 20 months & \\
\hline Area $\mathrm{Rq}$ & $3 \mathrm{~kW}$ solar PV & $18 \mathrm{~m}^{2}$ & \\
\hline
\end{tabular}

cycles and increasing the life of storage. If due to any reason, the battery is not fully charged from solar PV, the utility charging could also be used. A little cost paid to utility for charging the batteries is better to increase the life of battery bank than replacing the battery banks every year hence increasing the cost annually. Studies show that the ideal control strategy for battery storage can increase the efficiency of battery bank [23-25] and ultimately reduce the induced inefficiency [26]. In line with the elevating demand for solar PV, DC microgrid is an encouraging technique to blend distributed generation, storage devices, and various types of load management and distribution techniques [27].

The second scenario is for the regular load and burst load. This system is grid operated as well as from solar PV based. As described above, regular load involves DC inverter technology whereas burst load involves schedule based appliances. These appliances could be run during opted time slots as shown in Figure 14. Power consumption by regular and burst load during different time slots is shown in Figure 15.

To evaluate the results, software Viewpower 2.14 is used to analyze the real-time data from EMS. Communication link RS242 is used to get input data for different parameters as shown in Figures 16 and 17. As shown in Figure 16, the solar power-based power generation during peak hours is compared with the load demand during the same time. It is observed that due to maximum sunlight during this time period, the PV-based generation exceeds the load demand hence various scheduled loads, for example, iron, washing machines, and other power-consuming appliances which mostly rely on utility, could be run at this time hence decreasing the utility cost along with extra charging of battery storage at this hour.

The intelligent timing calculated for maximum usage of PV-based power can be a big achievement in a smart house. The graph in Figure 17 explains various power generations and loads in terms of watts. As observed, during daylight, maximum PV-based power generation occurs; hence, the demand for utility-based power is almost negligible and the whole system could be running entirely on the PV-based system. But, after sunset, it can be observed that the system relies either on utility or the charged batteries during daytime by PV system. As it is observed in Figure 17 as well, the running of high load during daytime results in a lessened demand for power supply during the nighttime hence decreasing the dependence of the system on utility and also preventing the full discharging of the batteries, leading to the stability and security of the entire electricity system.

\section{Cost Estimation}

Solar PV system along with EMS consists of the following items. The whole system costs more than $279 \mathrm{k}$ PKR. A minimum of $18 \mathrm{~m}^{2}$ rooftop is required for installation of $3 \mathrm{~kW}$ solar PV arrays. It saves utility bill to approximately $77.5 \%$ per month in terms of running cost and also excluding the fuel cost for generator. EMS improves the overall system efficiency and system stability further decreasing the running cost and increasing system reliability and effortlessness techniques for continuous supply of electricity during hours of load shedding and problematic conditions in Pakistan. Managing maximum load during PV peak generation hours enhances the efficiency of the proposed system. Using data from the weather forecast, this system schedules various power-consuming tasks more intelligently. It saves battery storage for unplanned load shedding at night hours to avoid a total blackout condition. Using real-time data from EMS, average cost estimation is done. It takes about 20 months for return on investment (ROI). Table 9 shows the detailed cost for the system, and Table 10 shows the saving in PKR and ROI. 


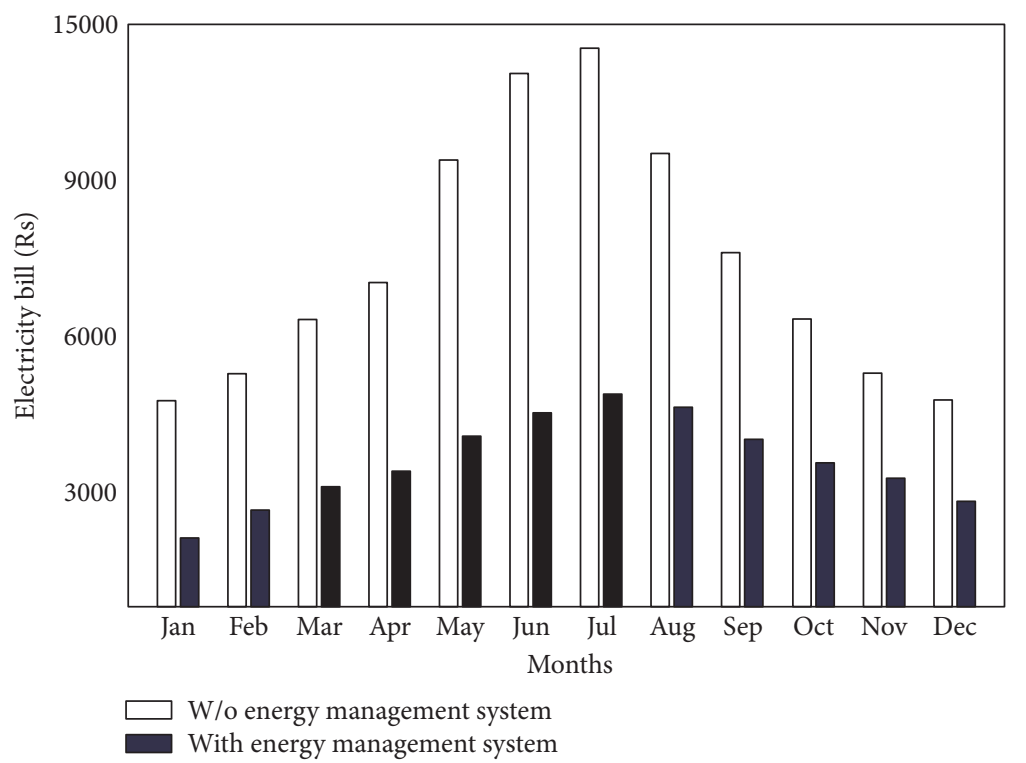

FIGURE 18: The impact of EMS on the monthly electricity cost.

The impact of EMS on the monthly electricity cost could easily be evaluated with the graph presented in Figure 18. The monthly cost mentioned was obtained from system using EMS techniques. As it can be seen that there is a radical difference in the monthly cost due to the proposed system, it not only makes the PV system more stable but also makes it highly cost-effective. Even during the peak power usage months in summer, it is observed that the EMS helps in keeping the monthly cost to a lower and almost constant level, thereby presenting it as an ideal system for residential loads.

\section{Conclusion}

EMS along with solar PV distributed generation is implemented successfully at domestic level for a specific home situated in an irregular load shedding area of Punjab, Pakistan. The mentioned techniques decrease the abrupt power shutdown during load shedding hours. Load-shifting techniques during peak load demand help the user to reschedule maximum power-consuming tasks during hours of maximum PV generation, with a positive intention of reducing utility tariff and generator fuel consumption. Intelligent appliance communicates with EMS further presenting an approach for power scheduling at a local level. The implemented work confirms massive reduction in terms of running cost and peak load for both utility and users. It demonstrates the real application of DC-AC network with existing infrastructure. The resulted outcomes are satisfactory and implemented along with the concept of smart grid. Also, the same strategy can be proposed and implemented to other consumers.

\section{Conflicts of Interest}

The authors declare that there is no conflict of interest regarding the publication of this paper.

\section{References}

[1] R. Batchu and M. P. Naran, "Multi-stage scheduling for a smart home with solar PV and battery energy storage," in Innovative Smart Grid Technologies - Asia (ISGT ASIA), IEEE, pp. 1-6, Bangkok, Thailand, November 2015.

[2] Y. K. Wu, C. R. Chen, and H. A. Rahman, "A novel hybrid model for short-term forecasting in PV power generation," International Journal of Photoenergy, vol. 2014, Article ID 569249, 9 pages, 2014.

[3] "Solar energy potential map of Pakistan," January 2017, http:// defence.pk/threads.

[4] B. Akos, "A smart home demand-side management system considering solar photovoltaic generation," in 5th International Youth Conference on Energy (IYCE), pp. 1-5, Pisa, Italy, May 2015.

[5] C. A. Hill, M. C. Such, D. Chan, J. Gonzalez, and W. M. Grady, "Battery energy storage for enabling integration of distributed solar power generation," Smart Grid IEEE Transaction, vol. 3, pp. 850-857, 2012, December 2016, http://ieeexplore.ieee.org/ document/6198748.

[6] D. Qinghui and C. Iun, "Improving the efficiency of solar photovoltaic power generation in several important ways," in International Technology and Innovation Conference, pp. 1-3, Xian, China, October 2009.

[7] R. Martinez, Y. Bolea, A. Grau, and H. Martinez, "Fractional DC-DC converter in solar power electrical generation system," in In the Proceeding of IEEE Conference on Emerging Technologies \& Factory Automation, pp. 1-6, Palma de Mallorca, Spain, September 2009.

[8] T. Harakawa and T. Tujimoto, "A proposal of efficiency improvement with solar power generation system," in In the Proceeding of 21 Annual Conference of IEEE Industrial Electronics Society, pp. 523-528, Denver, CO, USA, November 2001.

[9] F. Liu, Y. Zhang, and S. Duan, "Comparison of P\&O and hill climbing MPPT methods for grid-connected PV converter," in International conference Industrial Electronics and Applications ICIEA, pp. 804-807, Singapore, June 2008. 
[10] R. G. Lee, H. Bae, and B. H. Cho, "Advanced incremental conductance MPPT algorithm with a variable step size," in 12th International Power Electronics and Motion Control Conference, pp. 603-607, Ljubljana, Slovenia, August-September 2006.

[11] R. G. Yadav, R. Anjan, S. A. Kharparde, and P. Pentayya, "India's fast-growing power sector-from regional development to the growth of a national grid," IEEE Power and Energy Magazine, vol. 3, pp. 39-48, 2005, December 2016, http:// ieeexplore.ieee.org/document/1458229.

[12] P. Kumar and S. Singh, "Reconfiguration of radial distribution system with static load models for loss minimization," in In the Proceeding of IEEE International Conference on Power Electronics Drives and Energy Systems (PEDES), pp. 1-5, Bombay, India, December 2014.

[13] I. Ali, M. S. Thomas, and P. Kumar, "Energy efficient reconfiguration for practical load combinations in distribution systems," lET Generation, Transmission and Distribution, vol. 9, pp. 1051-1060, 2015, http://ieeexplore.ieee.org/ document/7173384.

[14] I. Ali, M. S. Thomas, and P. Kumar, "Effect of loading pattern on the performance of reconfigured medium size distribution system," in Proceeding of fifth IEEE Power India Conference, pp. 1-6, India, December 2012.

[15] S. Rauf, S. Rasool, M. Rizwan, M. Yousaf, and N. Khan, "Domestic electrical load management using smart grid," in 3rd International Conference on Power and Energy Systems Engineering CPESE, pp. 1-8, Kitakyushu, Japan, September 2016.

[16] "Comparison of DC inverter vs non-inverter technology," January 2017, http://www.morenews.pk/dc-inverter.

[17] M. J. Sarker, B. Asare-Bediako, J. G. Slootweg, W. L. Kling, and B. Alipuria, "DC micro-grid with distributed generation for rural electrification," in 47th International Universities Power Engineering Conference (UPEC), pp. 1-6, Brunel, United Kingdom, September 2012.

[18] T. Kaipia, "Impact of low voltage DC system on reliability of electricity distribution," in 20th International Conference and Exhibition on Electricity Distribution, pp. 1-4, Prague, June 2009.

[19] T. Shibata, K. Sakai, and Y. Okabe, "Design and implementation of an on-demand DC grid in home," in IEEE/IPSJ International Symposium on Applications and the Internet, pp. 152-159, Munich, July 2011.

[20] M. Ton, B. Fortenbery, and W. Tschudi, "DC power for improved data center efficiency," Lawrence Berkeley National Laboratory Report U.S. Department of Energy, WA, USA, 2007.

[21] M. Saeedifard, M. Graovac, R. F. Dias, and R. Iravani, "DC power systems: challenges and opportunities," in IEEE Power Engineering Society General Meeting, pp. 1-7, Providence, RI, USA, 2010.

[22] Y. Yang and F. Blaabjerg, "Low-voltage ride-through capability of a single-stage single-phase photovoltaic system connected to the low-voltage grid," International Journal of Photoenergy, vol. 2013, Article ID 257487, 9 pages, 2013.

[23] J. Marcos, O. Storkël, L. Marroyo, M. Garcia, and E. Lorenzo, "Storage requirements for PV power ramp-rate control," Solar Energy, vol. 99, pp. 28-35, 2014.
[24] I. De la Parra, J. Marcos, M. García, and L. Marroyo, “Control strategies to use the minimum energy storage requirement for PV power ramp-rate control," Solar Energy, vol. 111, pp. 332343, 2015.

[25] J. Marcos, I. de la Parra, M. García, and L. Marroyo, "Control strategies to smooth short-term power fluctuations in large photovoltaic plants using battery storage systems," Energies, vol. 7, no. 10, pp. 6593-6619, 2014.

[26] C. Rus-Casas, J. D. Aguilar, P. Rodrigo, F. Almonacid, and P. J. Pérez-Higueras, "Classification of methods for annual energy harvesting calculations of photovoltaic generators," Energy Conversionand Management, vol. 78, pp. 527-536, 2014.

[27] M. Sechilariu, F. Locment, and B. Wang, "Photovoltaic electricity for sustainable building. Efficiency and energy cost reduction for isolated DC microgrid," Energies, vol. 8, pp. 7945-7967, 2015. 

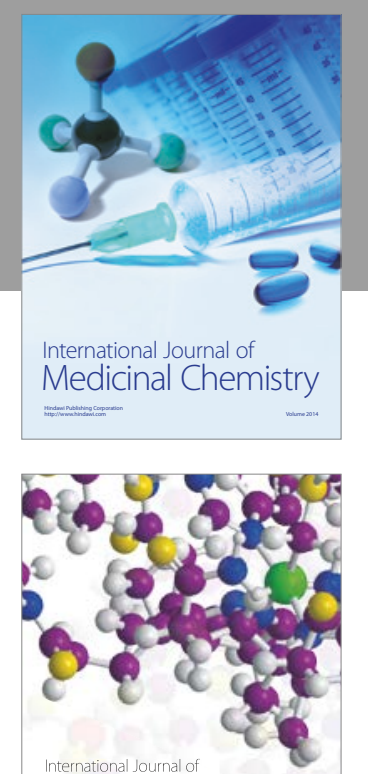

Carbohydrate Chemistry

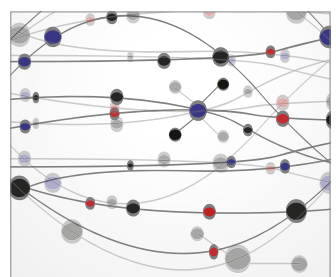

The Scientific World Journal
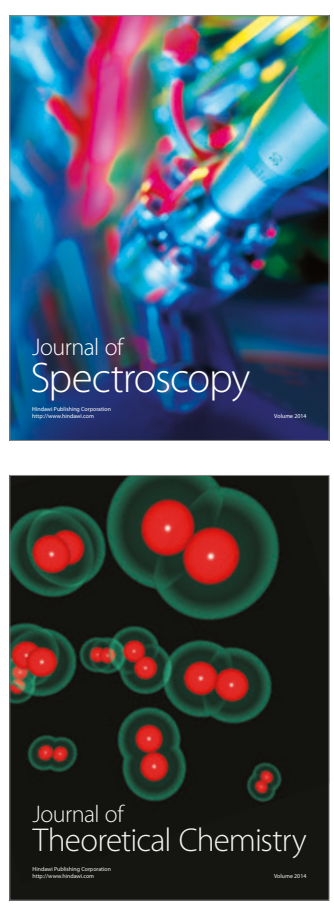
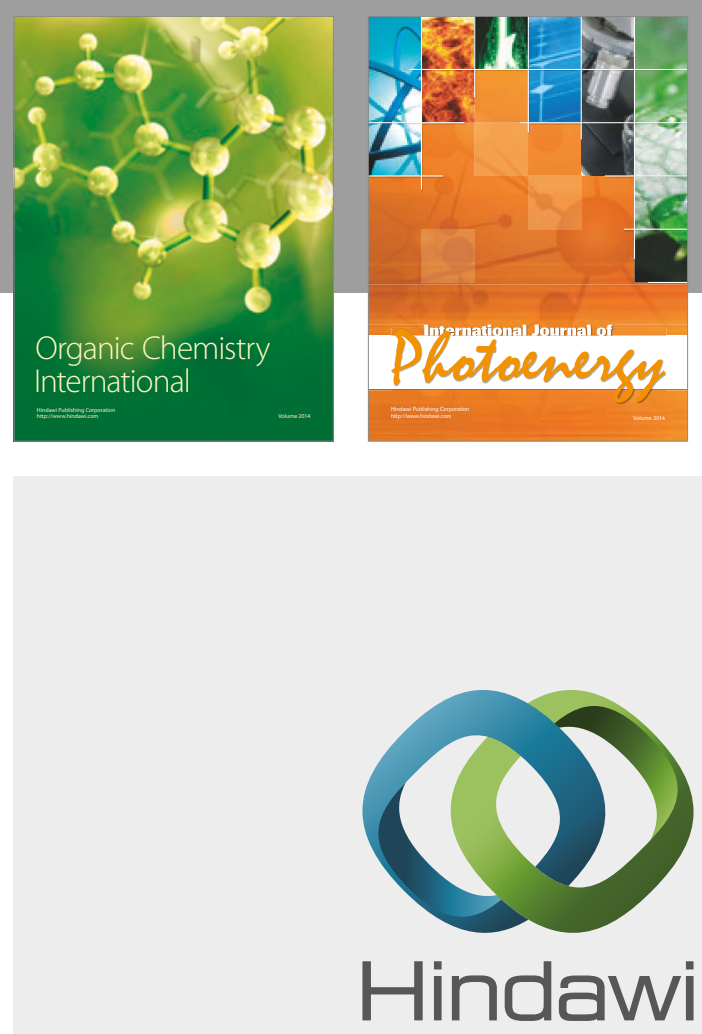

Submit your manuscripts at

https://www.hindawi.com

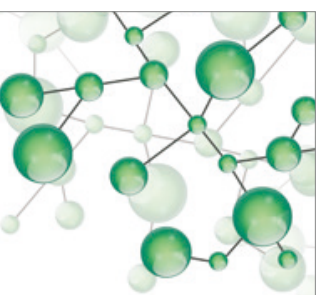

International Journal of

Inorganic Chemistry

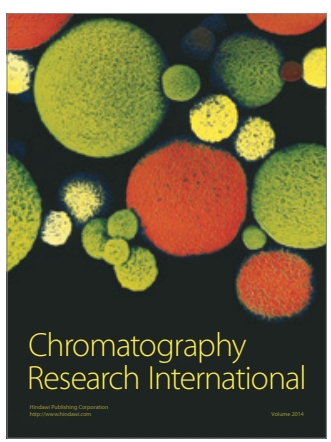

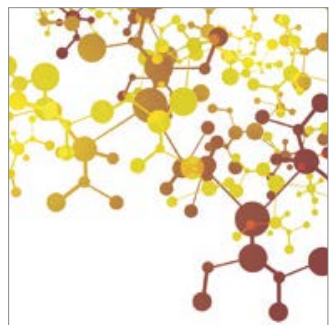

Applied Chemistry
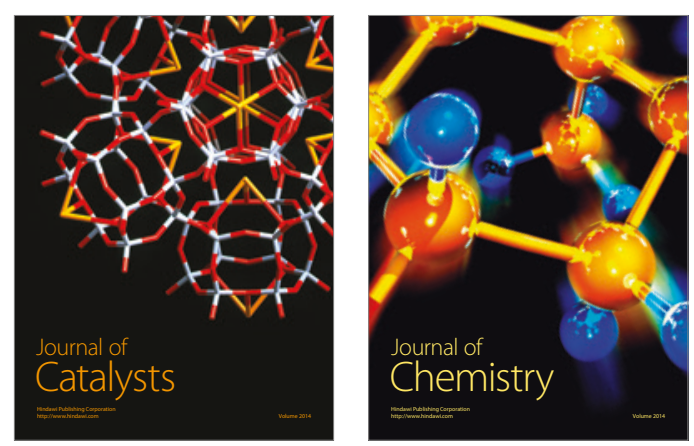
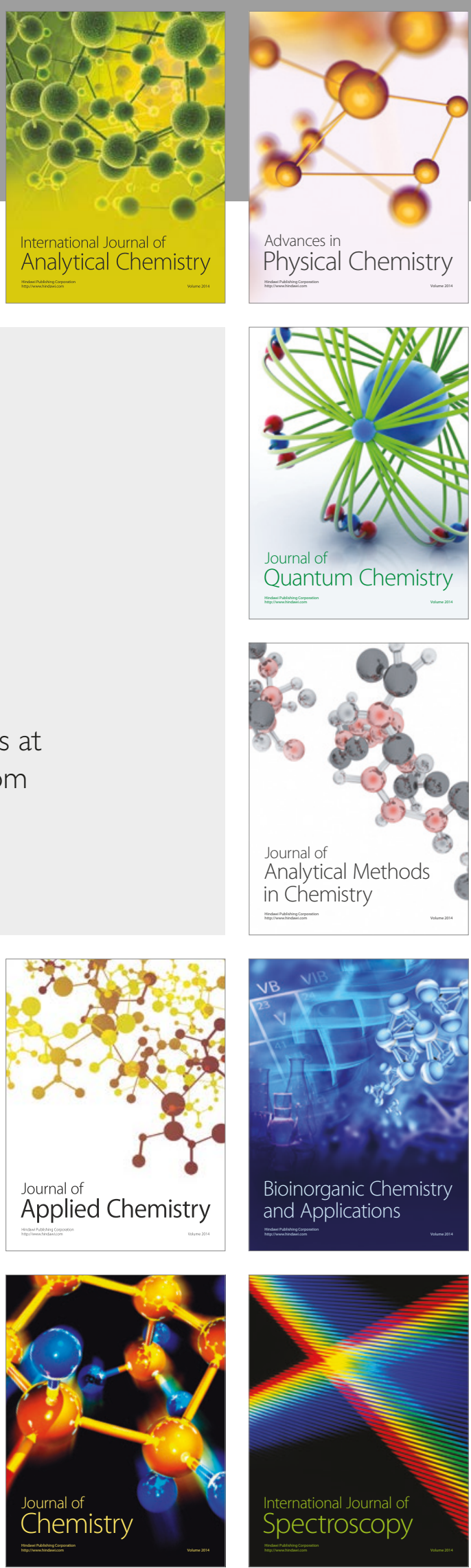